\title{
COVID-19: The Questions Ahead for Future Pedestrian Ways in Transit Area
}

\author{
Anita R Rakhmatulloh*, Diah I Kusumodewi, Djoko Suwandono \\ Urban and Regional Planning Department, Diponegoro Unversity, Indonesia
}

\begin{abstract}
Managing epidemics will be more complicated for cities that have high levels of urbanization. This is exacerbated by the use of public transportation modes, which can be one of the places where there is a high risk of spreading the virus. Prevention of spreading through clean living patterns, and maintaining distance in open areas such as public vehicles, public places, and pedestrian routes is important to reduce the spread of COVID-19. This research aims to find out the condition of pedestrian ways in the Jakarta transit area to be able to plan the design of pedestrian ways following health protocols that can prevent the spread of the virus in the future-using descriptive methods. Data is obtained from secondary data and health regulations/protocols issued by data provider institutions related to COVID-19. Data were analyzed using the descriptive analysis to get the results of the discussion juxtaposed with related theories. The results showed that city planning needs innovation to prepare the city to be more resilient when facing a pandemic. Innovation planning in the pedestrian route widens the lane and circulation, using automatic doors in-transit area and new street furniture that can reduce the risk of spreading the virus.
\end{abstract}

\section{Introduction}

Managing epidemics is more complicated for cities with high levels of urbanization and has contemporary urbanization[1]. Jakarta is the capital of Indonesia, a city that has a high level of urbanization because it functions as a business and government center. People who live in the area around Jakarta (BODETABEK: Bogor, Depok, Tangerang, Bekasi) commute from their place of residence to Jakarta to work. Rapid and massive urbanization is seen as a possible factor for the spread of infectious diseases[2]. According to Acuto, the spread of COVID-19 throughout the world is a story of village-to-city connectivity and vice versa[3]. The first German case was confirmed near Munich, Bavaria, due to a worker in a parts factory in Wuhan flying to Germany to provide training in Bavaria. From Bavaria, Corona spread so quickly to various regions in Germany $[4,3,5]$. In Indonesia, the first case of contracting the coronavirus was due to contact with Japanese citizens who came to Indonesia to attend a dance. This illustrates that interactions between people from different regions cause the spread of coronavirus.

\footnotetext{
* Corresponding author: anita.ratnasari.r@gmail.com
} 
The science of urban planning has evolved quite a long time because it has solved different city problems each time. In 1851, the concept of physical planning was formally introduced by Ebenezer Howard through the idea of "The Garden City of Tomorrow" over the problem of urban physical quality decline due to urbanization and industrialization after the industrial revolution [6]. The cholera epidemic in the 19th century triggered the introduction of modern urban sanitation systems. Urban planning continues to grow in line with an awareness of environmental sustainability to be sustainable. Until now, the smart city concept emerged that utilizes ICT (information and communication technology).

The spread of coronavirus highlights the urban system's fragility in the face of transmission and the need for careful preparation to respond to the emergence of the pandemic[7]. COVID-19 pandemic has an influence on urban planning in terms of evaluating the availability and quality of basic infrastructure, inter-regional integration, availability of blue and green open spaces, city-regional planning that is more integrated with the economic sector, energy, transportation networks, food production, and data provision clear and accountable[8]. Likewise, it must be done in the planning of pedestrian ways in the transit area.

More and more populations in urban areas that are connected by mass public transportation will increase the risk of epidemics. This is in line with what was stated by Dr. Steven Goodman, an epidemiologist at Stanford University, who said that overcrowding is a big enemy in the current situation[9]. High density will make it difficult to track contacts, especially causal contact in public areas [10], how to plan the transit area, which is the point that connects the mass public transportation service network, which of course, there is a buildup of time in the area, how to plan a pedestrian route that is still well connected to the public transportation system but can still provide safe services for the public on health aspects. The ongoing COVID-19 epidemic presents major challenges for urban management or even urban planning. Therefore, it is very important to study the current handling of epidemics using prevention methods to prevent future outbreaks[11]. Preparedness is an important investment because it costs less than the impact of a health emergency if an outbreak occurs[10].

The existence of the COVID-19 pandemic has resulted in changes in behavior and space in urban areas. The need for activities that do not allow to perform in virtual space is still very large, especially related to production activities. The moving needs of the urban community must remain contained in more efficient and sustainable mass public vehicles.

Pandemics can spread in global-local scale transportation patterns due to the interaction of cities in local-global-local transportation patterns. Physical interaction within the city through the transportation network then spread globally due to international travel and will spread into the city again[12]. Mass transportation has a high risk of spreading if too many passengers are transported, but ventilation is limited; it cannot identify passengers who are potentially sick, and various types of facilities are touched (ticket machines, handrails, doorknobs, etc.)[13]. The transit center has been equipped with cameras, sensors, and other technologies to reduce human interaction, queuing, and detect passenger's health conditions through thermal sensors made[14]. This progress will make people more able to choose positions that are considered safe for them when choosing public transportation or being in a transit location. Changes in people's habits will change because of this pandemic.

Public transportation (buses, trams, trains) that are used often carry passengers overcapacity; this can contribute to the spread of disease among passengers using public transportation[15]. Workers who are required to come to the office are at risk of contracting the virus during the trip. Working from home can reduce density on public transportation. As the experience of Jakarta City, which controls demand by changing schedules, has resulted in higher passenger density, it is reminded that it is necessary to conduct a comprehensive impact assessment before implementing the policy to avoid the rebound effect[16]. 
In order to carry out safe mobility while maintaining distance, wide, meaningful, and accessible road spaces are needed for all city residents. The pedestrian ways must be a good facility provided by the government[17]. Compressed air and noise pollution, increased driving safety, and decreasing emissions from motor vehicles are a positive impact on reducing community mobility during the pandemic. It can be an opportunity to improve people's habits of using the pedestrian lane due to increasingly deserted road lanes[18].

The recent phenomenon of COVID-19 is one of the challenges in urban planning and design. Population mobility, especially using mass public transportation facilities, can quickly spread the virus between people. Mass public transportation, which has been encouraged to be developed in urban transportation systems, has become a dilemma because it can become a medium for spreading disease outbreaks. City planning and design are needed that understands the needs of this health aspect in the future. This study aims to determine the condition of the pedestrian ways in the transit area of Jakarta to be able to plan the design of the pedestrian ways following health protocols that can prevent the spread of the virus in the future.

\section{Literature Review}

The location of activities has an important role in the selection of pedestrian activities[19]. In the context of the location of the transit center, a pedestrian activity can be different from pedestrian activity in other locations. According to Gehl (2011), activities that can be created in the pedestrian include walking, standing, standing to talk with someone, standing and stopping for a while, and so forth. In the context of transit, pedestrian activities can take the form of brisk walking, marching, leisurely walking, waiting, eating, drinking, standing to talk with someone, standing and stopping for a while, etc. [20, 21]. One of the factors affecting pedestrian behavior is the typology of pedestrians[22].

Pedestrian ways need to pay attention to user behavior so that the investment can be following the target. Pedestrian-oriented design is an important component in the feasibility of transit[23]. Roads in TOD can be designed to slow traffic and minimize pedestrian crossings aimed at increasing pedestrian activity in the transit stop area. Making pedestrians feel comfortable and safe by widening the pedestrian ways, slowing down, and managing car traffic around the transit area[24]. The good pedestrian design must take into account the needs of all potential users, including people who have physical or mental limitations[25]. Pedestrian safety and comfort are crucial for successful transit-oriented development[24].

The government has not yet issued special rules on the pedestrian ways, but regulations in public places and public transportation can be used as an effort to prevent the spread of COVID-19. These rules include Ministerial Regulation No 9/2020 concerning Guidelines for the Implementation of PSBB and DKI Jakarta Governor Regulation No 33 of 2020 concerning Implementation of PSBB in DKI Jakarta. The use of masks outside the room and keep each other a very important thing when doing activities outside the home. These rules also regulate activities that are allowed in public open spaces while maintaining health protocols to reduce the spread of the virus.

\section{Method}

The research method is defined as a scientific method used to obtain data with specific purposes and uses [26, 27]. This research uses descriptive analysis method. Data were obtained from literature studies and data provider institutions related to COVID-19. Data were analyzed using the descriptive analysis to get the results of the discussion juxtaposed with related theories. 


\section{Result and Discussion}

\subsection{Pedestrian Ways Conditions}

The existence of pedestrian ways makes it easier for users to move from one place to another without using motorized vehicles. In transit activities, passengers must travel by foot from one mode to another. The level of pedestrians' movement in the Jakarta Transit Area is very high and congested, especially during peak hours, namely morning (06.00-09.00 a.m.) and evening (03.00-07.00 p.m.). Pedestrians are dominated by office employees who work around the transit area, such as the Jakarta Economic Strategic Area Sudirman Central Business District, who travel to and from work with the modes of transportation provided[28]. The transit area in the city of Jakarta includes the meeting of various modes of mass transportation such as KRL, Trans Jakarta Bus, MRT, and Airport Train (Fig.4).

Commuter line or KRL is an electric train transporting passengers to and from the Greater Jakarta Metropolitan Area (Jabodetabek), including Jakarta City, Bogor City, and Bogor Regency, Depok City, Tangerang City, Tangerang Selatan City, Lebak Regency, Bekasi City, and Bekasi Regency. KRL has a total of 80 stations, and six lines spread throughout Jabodetabek. The following is a map of the commuter line (KRL) train routes in Jabodetabek. Overall, the daily KRL passengers peaked in June 2018, which reached 1,154,080 passengers on weekdays, if viewed based on KRL passenger data per month, KRL passengers peaked in October at 29,316,976 passengers[29]. The following are complementary tools at the KRL Station to meet user needs can be seen in Figure 1.

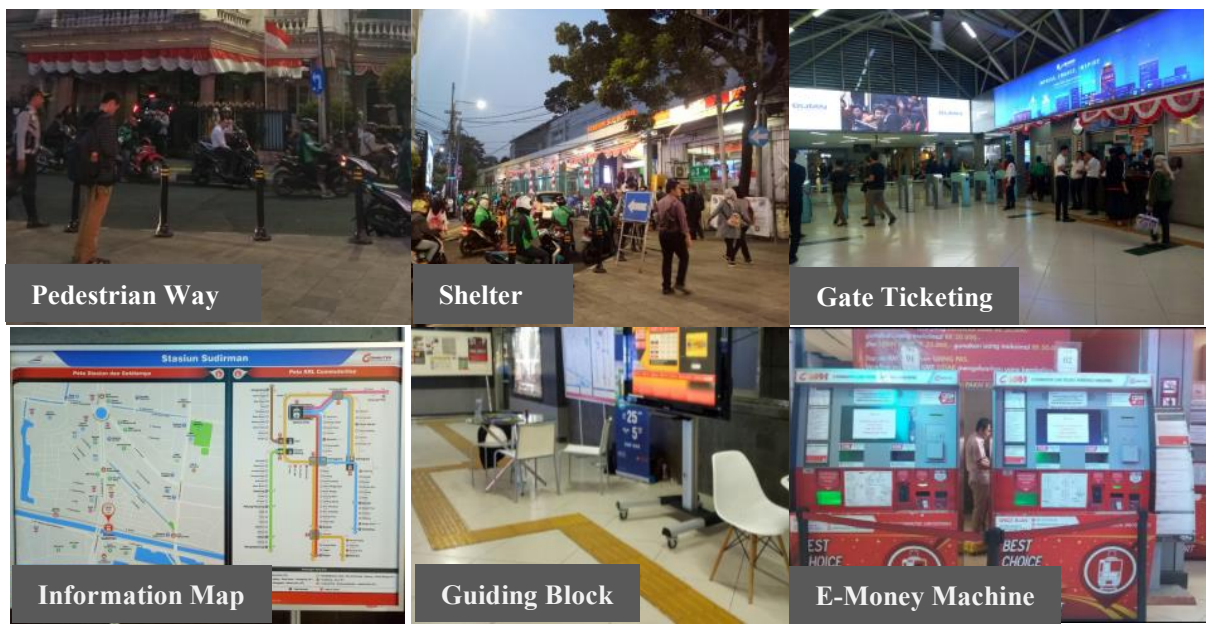

Fig. 1. Circulation And Supporting Facilities for Commuter Line Users

From the picture above we can find out the facilities in the commuter line transit area. facing the current pandemic conditions, facilities available at the commuter line such as gate ticketing and e-money machines must be a concern because these two facilities are places where people gather before using the commuter line. Managers can deal with it by giving massive information to commuter line users to pay more attention to the amount of their emoney balance. So they don't need to queue to buy tickets and refill their e-money at this facility. 
The availability of pedestrian way disabilities, clear and easily legible signage, and the floor in good condition makes it easy for transport users to mobility in the transit area. The transit area is also equipped with several waiting chairs. Purchasing tickets and filling emoney is also easy to do. Clear instructions and alert staff make it easy for public transport users to carry out activities such as transport mode changes and platform changes in commuter line transit areas.

TransJakarta is a Bus Rapid Transit (BRT) system in DKI Jakarta. TransJakarta is operated by PT. Jakarta Transportation under the auspices of DKI Jakarta BUMD. TransJakarta has 2,258 buses operating in all regions of DKI Jakarta [29]. All buses operating in DKI Jakarta, these buses operate in 13 routes with the total number of passengers in 2018 reaching 186,134,432 passengers. Complementary facilities/infrastructure at the Trans Jakarta shelter such as e-money charging counters, e-ticketing machines, zebra crossers, and low deck Transjakarta bus stop feeders are available in well-maintained conditions and can be enjoyed by pedestrians. The provision of complementary facilities at the bus stops in Trans Jakarta makes pedestrians have many choices for activities in the bus stop area. TransJakarta users can also use the bench while waiting for the bus.

Mass Rapid Transit Jakarta is a transportation system that uses fast electric trains in DKI Jakarta. The use of the Jakarta MRT was inaugurated on March 24, 2019. The MRT construction was divided into 3 phases, namely, phases I, II, and III. In 2019, the MRT that was inaugurated will be a phase I on the Lebak Bulus - HI Roundabout route and has a total route length of $15.7 \mathrm{~km}$ with 173,000 passengers per day [30]. The following are complimentary facilities available at the MRT Station to meet user needs Figure.2. During COVD-19, Indonesia Governor gives protocol in the public transportation areas such as body temperature detection. It can be due in check-in machines to monitor passenger body temperature. it would be better if the body temperature of public transport users can be seen using a thermal sensor/Temperature-Taking Infrared Cameras installed at the entrance of the transit area so that it is easier to monitor the user as done by China[31].

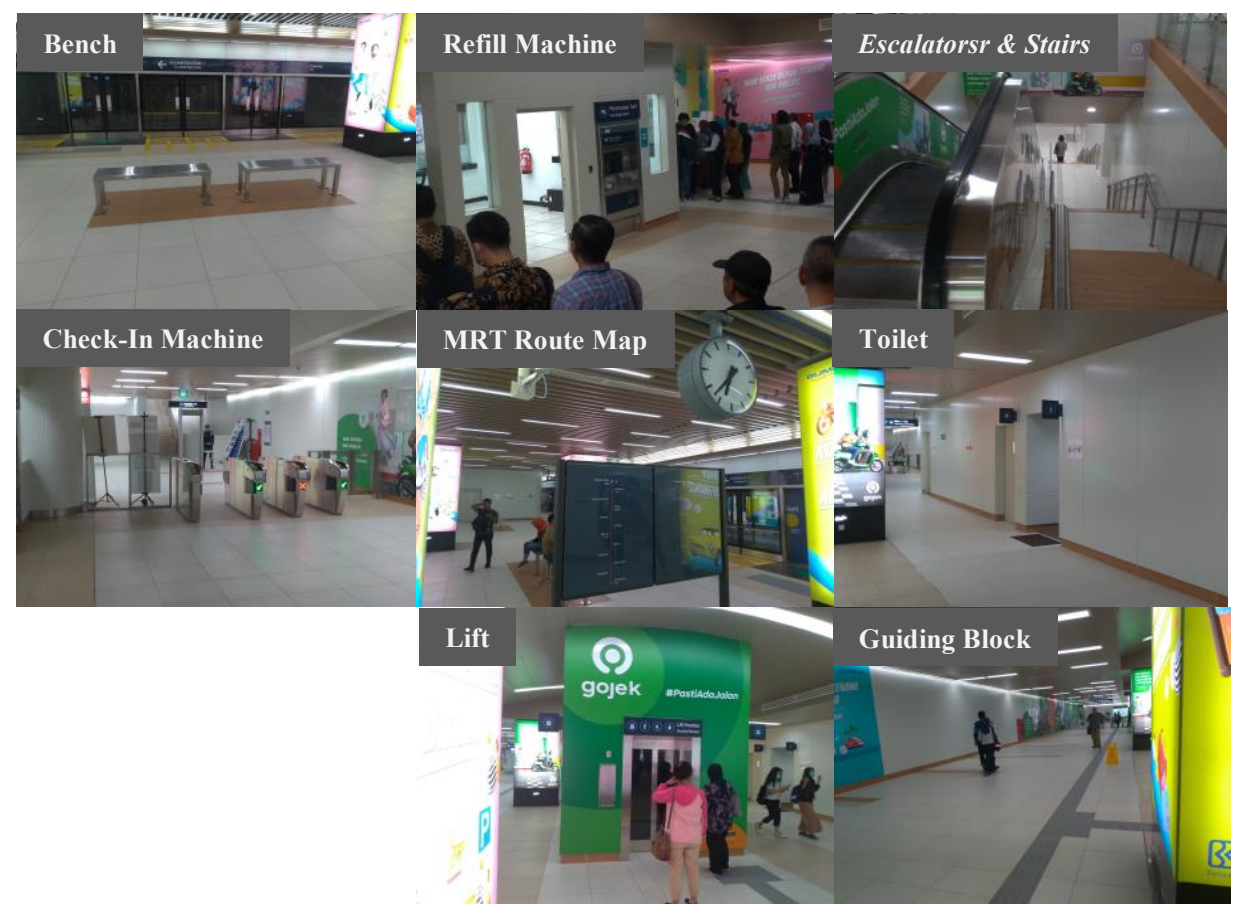


Fig. 2. MRT Station Complimentary Infrastructure Facilities

The facilities available in the MRT transit area are more modern, new, and spacious when compared to the facilities available in the KRL transit area and TransJakarta Bus Stop. Apart from the fact that the MRT station is still classified as a new facility, MRT applies a more expensive tariff compared to KRL and TransJakarta so that the facilities provided to users are better than that. The availability of elevators and escalators in the MRT transit area makes pedestrians easy to get in and out of the MRT station. This facility is certainly very useful for users who have physical limitations.

The BNI City Airport Station was originally known as the Sudirman Baru Station, but then the name changed to the BNI City Airport Train Station. The BNI City Airport Train Station was inaugurated on January 2, 2018, which has an area of 21,748.63 m². The BNI City Airport Train only serves trains in the direction of Soekarno-Hatta Airport. Like a train that serves passengers to the airport, the BNI City Airport Train Station has various facilities/infrastructure to meet the needs of its users. The following are the complementary facilities/infrastructure found around the BNI City Airport Train Station in Figure.3.
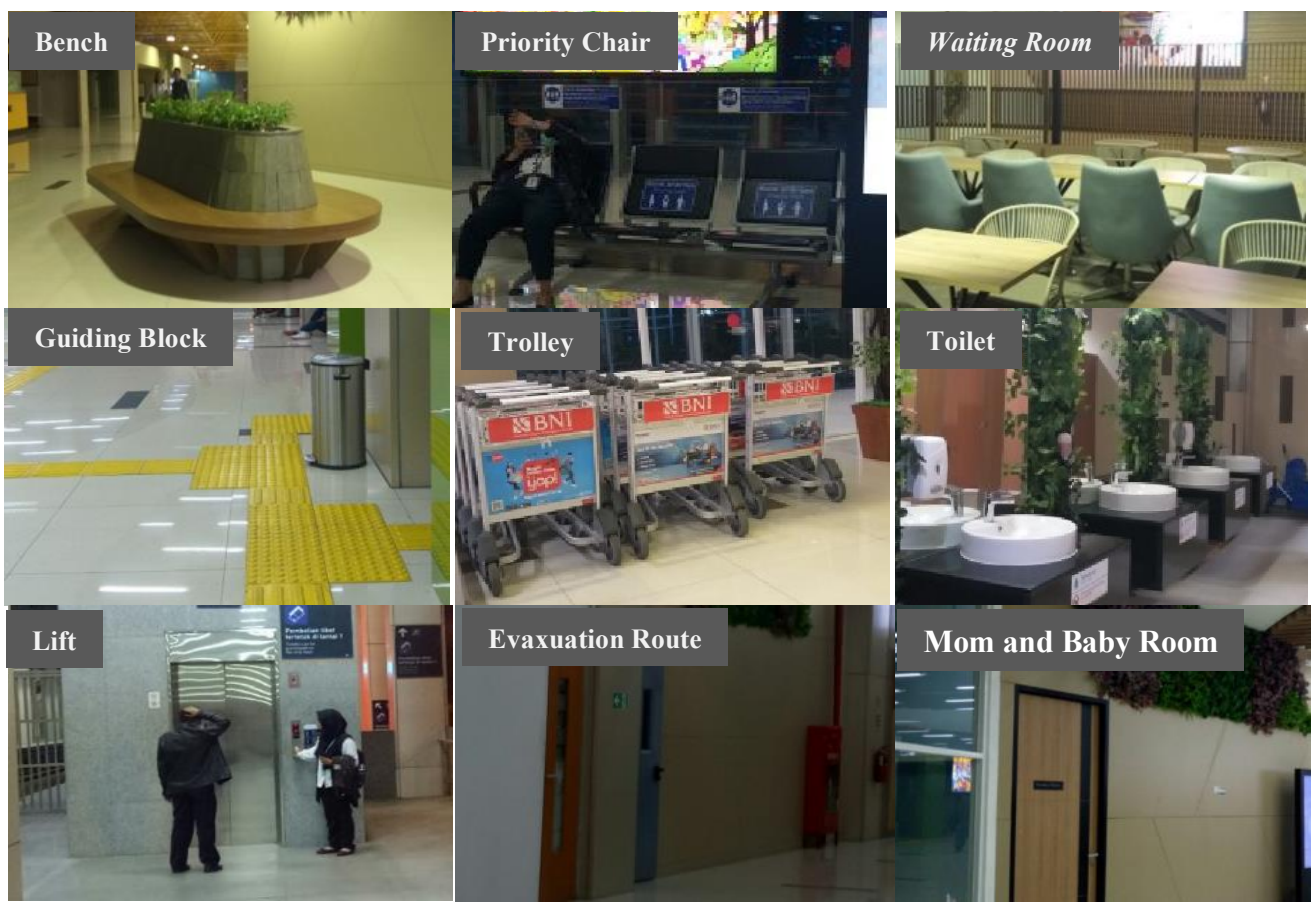

Fig. 3. Supporting Infrastructure Facilities at the BNI City Airport Train Station

During the pandemic, airport train management has appealed to all passengers to pay attention to scheduled departures, the seat selection in the train about the distance between passengers, and when waiting in line. The management also reduced the number of passengers by established regulations. Passengers are also asked to pay attention to the distance while in the station area. Spraying disinfectants and providing hand-sanitizers are always carried out by managers to prevent the spread of viruses.

Under its function as an airport train station, BNI City station provides complete facilities to airport train users. The waiting room is very important for airport train users. Providing complete facilities makes it very easy for pedestrians to move in the transit area of the BNI 
City Airport Train Station. Mobility in and out of the station area is easy because the signage as a pointer is clearly placed and easily readable.

Each station always has pedestrian ways and other supporting facilities for pedestrians. Besides, there are disabled pedestrian ways and lifts intended to help people with disabilities walk when using public transportation. Another supporting infrastructure is adapted to the different activities and needs of each station, such as waiting rooms, trolleys, and mother and child rooms provide in the airport train station are not owned by other types of transportation stations. As a whole, facilities for each station have adjusted to pedestrian needs [23].

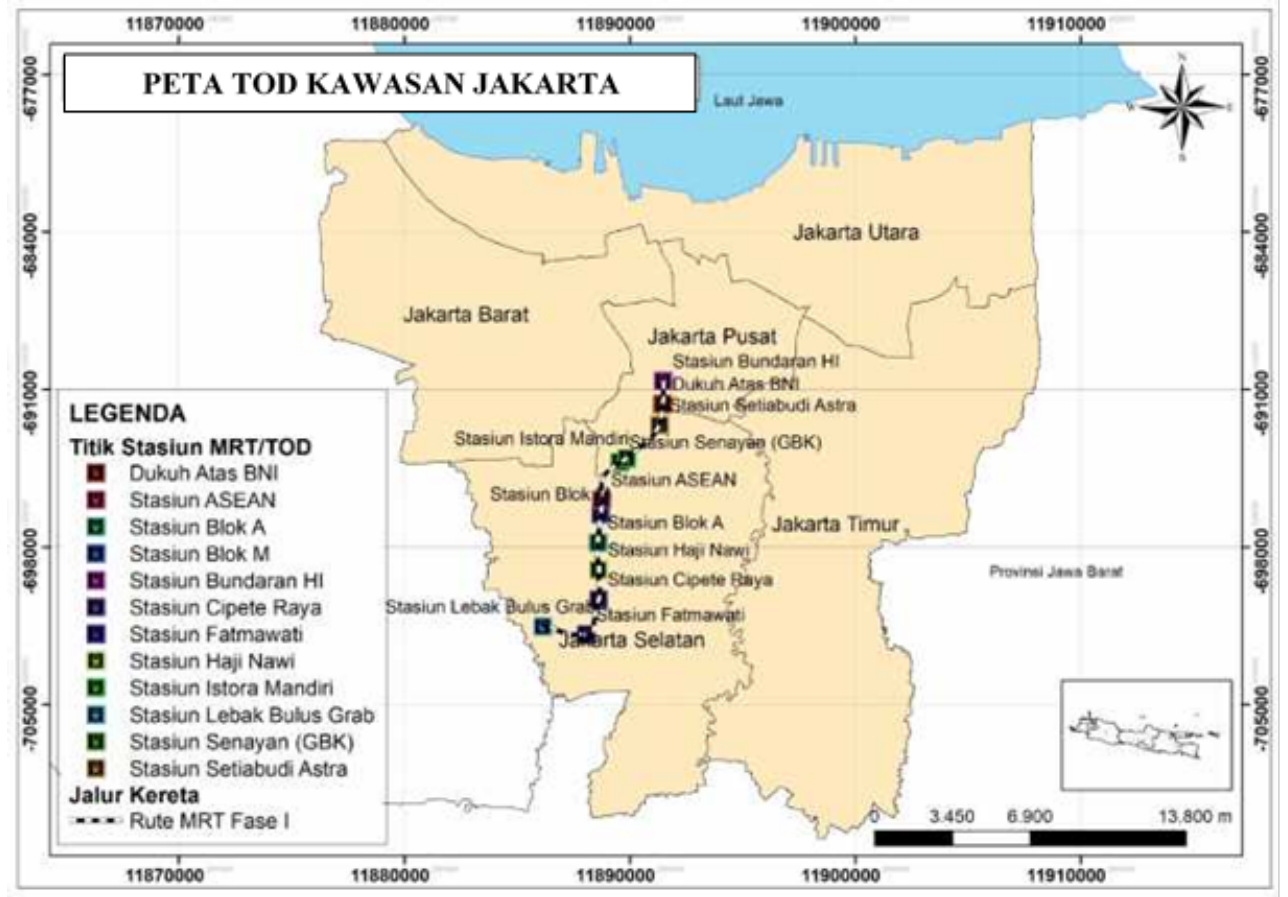

Fig.4. Map of TOD Jakarta Region

The DKI Jakarta Government has carried out various development programs in the provision of facilities and infrastructure to facilitate the needs of pedestrians at the transit center. Some of them are converting Kendal Street into a pedestrian line so that the four modes of transportation can be connected, connecting Sudirman KRL Station with the Airport Railway Station with pedestrian-friendly routes for pedestrians carrying luggage, and in the future will build a skywalk to connect the Hamlet Area Top with the LRT station. The following is the condition of facilities/infrastructure supporting pedestrian lines that are around the transit area can be seen in Figure 5.

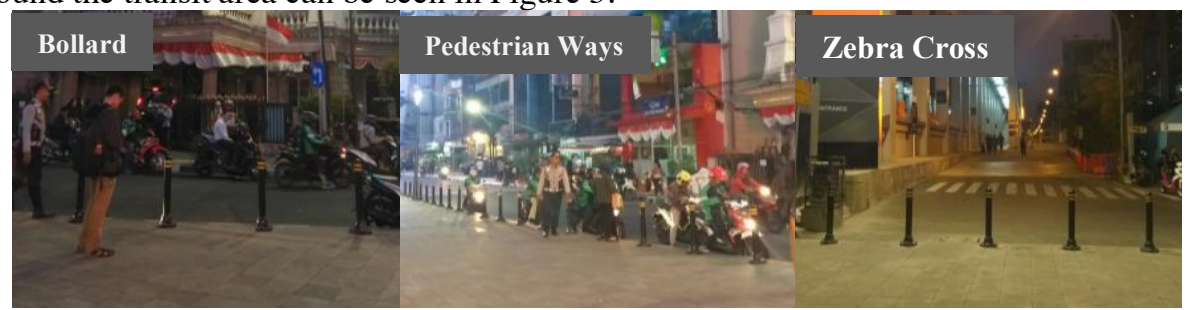




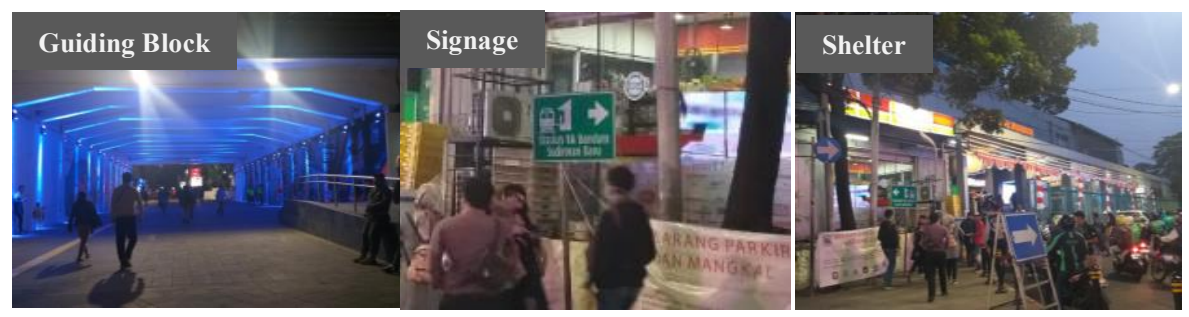

Fig. 5. Supporting Facilities in the Jakarta Transit Area Pedestrian Route

Pedestrian ways are following the technical requirements of the Ministry of Public Works of the Republic of Indonesia No. 3/2014 with various supporting facilities to ensure the safety, security, and comfort of users such as drainage, green lines, lighting, seating, safety fences, trash bins, markers and signs, signage, bus shelters and booths, and public telephones [32]. However, during this pandemic, it is necessary to pay attention to additional facilities in the pedestrian area to support health protocols about preventing the spread of the virus. The use of the latest technology is also needed to monitor pedestrian conditions. So that the possibility of spreading the virus in the pedestrian ways will be smaller.

\subsection{New Normal: Pedestrian Ways and Health Protocol}

Government Regulation No. 21/2020 concerning Large-Scale Social Restrictions (PSBB) in the Framework of Accelerating Handling of Coronavirus Disease regulates that the Minister of Health determines Large-Scale Social Restrictions based on the proposal of the governor/regent/mayor or Chief Executive of the Task Force for the Acceleration of Coronavirus Handling Disease 2019 (COVID-19), with established criteria, the prerequisites for the introduction of PSBB are the fulfillment of disease situation criteria in the form of a significant increase in the number of cases and deaths due to disease, the rapid spread of cases to several regions, and there are epidemiological links with similar events in the region or other countries[33]. Determination of PSBB by the Minister is based on a significant increase in the number of cases and deaths in a certain time, the rapid spread of cases in other regions within a certain time, and there is evidence that occurred t local transmission. In the Government Regulation, the PSBB at least covers the consolation of schools and workplaces, restrictions on religious activities, and restrictions on activities in public places or facilities. If the Minister has stipulated the PSBB, the Regional Government is obliged to implement and pay attention to the provisions of Law Number 6/2018 concerning Health Quarantine.

The Jakarta City Government-issued Governor Regulation No. 33/2020 to limit the activities and movements of people and goods and increase the anticipation of the development of the escalation of the spread of Coronavirus Disease (COVID-19). The Governor applies PSBB in the Province of DKI Jakarta, which is carried out in the form of restrictions on outdoor activities carried out by everyone who is domiciled or has activities in the DKI Jakarta Province. During PSBB, the community is required to wear masks outside the home.

During the implementation of the PSBB, some workers work in offices and at home. This condition resulted in a reduction in the mobility of workers in office areas. They are restricting modes of passenger transportation, either public or private, by taking into account the number of passengers (maximum 50\% of the capacity of the transport) and maintaining a distance between passengers (at least in the range of 1 meter) [32,33].

Facilities supporting activities in the transit area must pay attention to health protocol guidelines. As several points in the station area, such as the location of ticket filling, eticketing/check-in machines, and elevators, must be monitored by the station clerk to pay 
attention to the distance between users of public transportation, it can be seen in Figure 6 . Ticketing services can be done by optimizing online ticket purchases or calls for charging emoney balances before using public transportation. The aim is to reduce the interaction of both officers with passengers and fellow passengers. This can be seen as an opportunity to rethink customer service, for example by using AI chatbots such as the Tokyo Metros Bebot, or accelerating the spread of payments without contact or cellular tickets[5].

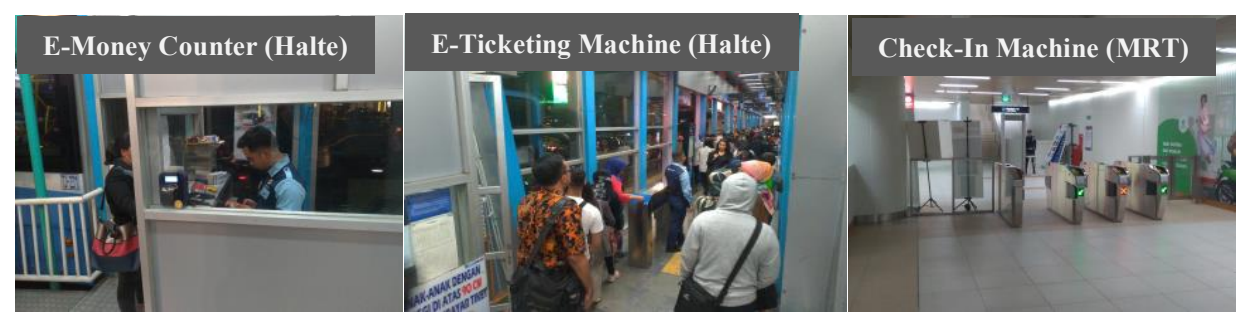

Fig.6. Public Transportation User Services in the Jakarta City Transit Area

Also, supervision is carried out by paying attention to supporting infrastructure for other pedestrian users, such as a bench. The distance between seat users in the transit area and pedestrian ways must be considered. Managers can provide a sign on the chair to urge users to stay away to reduce the risk of transmission of the virus. Maintenance tasks and infrastructure work may need to be reviewed to integrate safe distance requirements. Public transport companies will also need new skills in managing operations during a pandemic[5]. Besides, completing the pedestrian ways with a handwashing spot, wide circulation, automatic door opener, room lighting modification with sunlight, waiting room design can also be a clean lifestyle, and mitigation for spreading viruses. The provision of this new utility in the pedestrian ways will reduce the risk of spreading the virus to users of public transportation because the hands as a media that are vulnerable to viruses will have been cleared when entering public transportation.

Health protocols issued by the government through central or regional government agency regulations provide technical recommendations in public transportation facilities. The government has not yet issued specific regulations in the area of pedestrian ways. However, the distance regulation between passengers can be assumed as one of the standard pedestrian lane widths in the transit area. Besides, the provision of handwashing facilities in pedestrian ways also becomes important as an effort to maintain cleanliness. It can also reduce the use of a hand sanitizer when passengers enter public transportation so that the officer's work only checks the passenger's temperature and ensures the distance between passengers in the mode of transportation only.

COVID-19 makes increasing the needed space pedestrian that has good quality. Some cities turn roads into pedestrians; in addition to being affordable, walking activities can promote healthy lifestyles, spur regional economic benefits, and are an integral part of people's access to public transportation. Milan, one of the most polluted cities in Europe, has announced plans to permanently convert 35 kilometers of roads into bicycle and pedestrian ways as part of efforts to restore its economy and encourage trade during the summer[35]. Cities have made policy changes to improve their bicycle and pedestrian infrastructure, Bogota added 72 miles of bicycle lanes, Berlin quickly tracked the creation of a new wave of bicycle lanes, Budapest installed temporary bicycle lanes on major highways[36]. In the future, the population will likely begin to rely heavily on walking and cycling[37].

Walking and biking are safe and easy ways in this pandemic, rather than using buses/trains, some buses or trains that operate are too crowded for drivers to keep their distance[36]. Responding to this condition, widening the pedestrian ways becomes very 
important to respond to the call for physical distancing and to anticipate future conditions. The re-design of pedestrian ways must keep in mind the needs of users and health protocols regarding physic distancing during the pandemic.

\section{Conclusion}

Facilities in pedestrian ways currently do not support health protocols. The system of movement of public transportation also does not fully support this direction. New technology to monitor the movement of passengers in public transportation and station area are needed to anticipate passenger health and safety. Local planning regulations must be modified to ensure that facilities are available and accessible at close range to support sustainable travel[5].

Efforts to reduce the risk of spreading in the pedestrian transit area can be made by widening the pedestrian ways. This aims to improve user comfort because the physical distance between public transportation users is very important during the current pandemic. Besides, completing the pedestrian ways with a handwashing spot, wide circulation, automatic door opener, room lighting modification with sunlight, waiting room design can also be a clean lifestyle, and mitigation for spreading viruses. The provision of this new utility in the pedestrian ways will reduce the risk of spreading the virus to users of public transportation because the hands as a media that are vulnerable to viruses will have been cleared when entering public transportation. Pedestrian-oriented design is an important component in the feasibility of transit because pedestrian safety and comfort are essential for successful transit-oriented development [23, 24].

\section{Acknowledgment}

This research was financially supported by The Faculty of Engineering, Diponegoro University, Indonesia through Strategic Research Grant 2020.

\section{References}

[1] M. Acuto, "COVID-19: Lessons for an Urban (izing) World," One Earth, (2020).

[2] V. J. Munster et al., "Outbreaks in a Rapidly Changing Central Africa - Lessons from Ebola," N. Engl.J.Med., (2018).

[3] I. Klaus, "Pandemics Are Also an Urban Planning Problem," CityLab, New York City, (2020).

[4] Spiegel, "Erster Fall des Coronavirus in Deutschland bestätigt," SPIEGEL Wissenschaft, SPIEGEL Wissenschaft, Germany, (2020).

[5] UITP, "COVID-19 Pandemic Resuming Public Transport Services Post-Lockdown," Belgium, (2020).

[6] E. Howard, Garden City of Tomorrow. London: Swans Sonnenschein \& co., ltd., (1902).

[7] S. Shamsuddin, "Resilience resistance: The challenges and implications of urban resilience implementation," Cities, vol. 103, p. 102763, (2020).

[8] R. van den Berg, "How Will COVID-19 Affect Urban Planning?," The City Fix, (2020).

[9] B. M. Rosenthal, "Density Is New York City's Big 'Enemy' in the Coronavirus Fight," The New York Times, New York City, (2020). 
[10] V. J. Lee, M. Ho, C. W. Kai, X. Aguilera, D. Heymann, and A. Wilder-Smith, "Epidemic preparedness in urban settings: new challenges and opportunities," Lancet Infect. Dis., vol. 20, pp. 527-529, (2020).

[11] L. Liu, "Emerging study on the transmission of the Novel Coronavirus (COVID19)from urban perspective: evidence from China," Cities, vol. 103, p. 102759, (2020).

[12] T. Papndreou, "Is The Coronavirus The Transportation Industry's Opportunity?" Forbes, (2020).

[13] UITP, "Management of COVID-19 Guidelines for Public Transport Operators," Belgium, (2020).

[14] D. Liddell, "COVID-19 could forever change how we travel-for better or worse." www.fastcompany.com, (2020).

[15] C. Musselwhite, E. Avineri, and Y. Susilo, "Editorial JTH 16-The Coronavirus Disease COVID-19 and implications for transport and health," J. Transp. Heal., vol. 16, 2020.

[16] SZBUS, "Combating Covid-19," (2020).

[17] L. Mauliani, A. W. Purwantiasning, and W. Aqlib, "Designing Better Environment by Providing Pedestrian Way for Pedestrian," Procedia - Soc. Behav. Sci., vol. 179, pp. 80-93, (2015).

[18] B. Eby, "How Might Personal Transportation Behaviors Change as a Result of COVID19, and What Does That Mean for Policy?," Enotrans.org, 07-Apr-2020.

[19] H. Timmermans, Pedestrian Behavior: Models, Data Collection, and Applications. UK: Emerald Group Publishing Limited, (2009).

[20] A. Rapoport, Human aspects of urban form. Pergamon, (1977).

[21] J. Gehl, Life Between Buildings: Using Public Space. Washington DC: IslandPress, (2011).

[22] S. Kurose, A. Deguchi, and S. Zhao, "Comparative Study of Pedestrian Behavior in Central Shopping Areas of East Asian Cities," in Pedestrian Behavior : Models, Data Collection and Applications, First., H. Timmermans, Ed. UK: Emerald Group Publishing Limited, (2009).

[23] I. Architecture, "Planning And Designing For Pedestrians : Model Guidelines for San Diego Region," San Diego, (2002).

[24] MC, "Pedestrian-Oriented Features I Guide for Transit-Oriented Development," (2006).

[25] D. Nabors, R. Schneider, D. Leven, K. Lieberman, and C. Mitchell, "Pedestrian Safety Guide for Transit Agencies," Washington, DC, (2008).

[26] J. W. Creswell, Research design: qualitative, quantitative, and mixed methods approaches, 4th Editio. United States Of America: SAGE Publications, Inc., (2014).

[27] Sugiyono, Metode Penelitian Pendidikan Pendekatan Kuantitatif, Kualitatif, dan R\&D. ALFABETA, (2015).

[28] A. Rafi'i and L. Prayogi, "Pendekatan Konsep TOD pada Penataan Massa di Kawasan Dukuh Atas," J. Arsit. PURWARUPA, vol. 3, no. 2, (2019).

[29] B. Badan Pusat Statistik, “DKI Jakarta Dalam Angka,” DKI Jakarta, (2019).

[30] L. Parinduri, "Penetapan Tarif Bersubsidi Penumpang Moda Raya Terpadu Jakarta Phase I," Semin. Nas. Tek. UISU, vol. 2, no. 1, pp. 21-26, (2019).

[31] J. Bogaisky, "Tech That Scans People For Fever In Big Demand Amid Coronavirus Crisis, Boosting Wuhan Company," Forbes, (2020).

[32] KemenPU, Peraturan Menteri Pekerjaan Umum No. 03/Prt/M/2014 Tentang Penyediaan dan Pemanfaatan Prasarana dan Sarana Ruang Pejalan Kaki di Perkotaan. (2014).

[33] Peraturan Menteri Kesehatan Republik Indonesia Nomor 9 Tahun 2020 Tentang Pedoman Pembatasan Sosial Berskala Besar Dalam Rangka Percepatan Penanganan CORONA VIRUS DISEASE (COVID-19). Indonesia, (2020).

[34] Peraturan Gubernur Daerah Khusus Ibukota Jakarta Nomor 33 Tahun 2020 Tentang 
Pelasanaan Pembatasan Sosial Berskala Besar Dalam Penanganan CORONA VIRUS DISEASE (COVID-19) di Provinsi Daerah Khusus Ibukota Jakarta. Indonesia, (2020). [35] B. Welle and S. Avelleda, "Safer, More Sustainable Transport in a Post-COVID-19 World," (2020).

[36] A. Davies, "The Pandemic Could Be an Opportunity to Remake Cities." WIRED, California, (2020).

[37] S. Tan, A. Fowers, D. Keating, and L. Tierney, "Amid the pandemic, public transit is highlighting inequalities in cities," The Washington Post, Washington DC, (2020). 